Article

\title{
Digital Commons and Citizen Coproduction in Smart Cities: Assessment of Brazilian Municipal E-Government Platforms
}

\author{
Maurício José Ribeiro Rotta ${ }^{1, *}$, Denilson Sell ${ }^{1,2}{ }^{\mathbb{D}}$, Roberto Carlos dos Santos Pacheco ${ }^{1}$ \\ and Tan Yigitcanlar ${ }^{3}$ (i) \\ 1 Department of Knowledge Engineering and Management, Federal University of Santa Catarina, \\ Campus Universitário Reitor João David Ferreira Lima, Florianopolis 88040-900, Brazil \\ 2 Department of Business Administration, State University of Santa Catarina, Av. Me. Benvenuta, 2007, \\ Itacorubi, Florianopolis 88035-001, Brazil \\ 3 School of Civil Engineering and Built Environment, Queensland University of Technology, 2 George Street, \\ Brisbane, QLD 4000, Australia \\ * Correspondence: maurotta@gmail.com; Tel.: +55-(48)-99144-4747
}

Received: 26 June 2019; Accepted: 9 July 2019; Published: 22 July 2019

check for updates

\begin{abstract}
Good governance practices through electronic government (eGov) platforms can be suitable instruments for strengthening the outcomes of smart city policies. While eGov is the application of information and communication technologies to public services, good governance defines how well public authorities manage public and social resources. Contemporary public management views, such as 'new public service', include citizen participation as a critical factor to sustainable government in smart cities. Public services, in the age of digital technology, need to not only be delivered through eGov platforms, but also need to be coproduced with the engagement of social players, e.g., citizens. In this sense, eGov platforms act as digital commons, and conceived as digital spaces, where citizens and public agents interact and collaborate. In this paper, we presented the Municipal eGov Platform Assessment Model (MEPA), which is a model specifically developed to evaluate eGov platforms regarding their potential to promote commons in smart cities. The study applied MEPA to 903 municipal websites across Brazil. The results revealed that the majority of investigated Brazilian eGov platforms have only a low level of digital commons maturity. This finding discloses less citizenship coproduction, and fewer opportunities for city smartness. As the MEPA model offers public authorities an instrument to depict weaknesses and strengths of municipal eGov platforms, its adoption provides an opportunity for authorities to plan and manage their platforms to act as promoters of digital commons and citizen coproduction.
\end{abstract}

Keywords: smart cities; commons; digital commons; governance; e-government; smart governance; new public service; Brazil

\section{Introduction}

When applied to cities, "smartness" refers to efficiently use human, social, natural and technological resources towards a sustainable urban living. There is an intrinsic connection between such challenges and the notion of "smart government" as public digital spaces with both authorities and citizenship participation, based on public (good) governance and efficient electronic government (eGov) [1,2]. In smart eGov platforms, public services are not only delivered by government, but include citizen participation supported by modern information technology [3]. In this sense, in developing initiatives and projects related to eGov, public administration can use a more humanistic approach, using the 
principles of the 'new public service' (NSP)—the focus of which is the public interest and the coproduction of the common good, and the public servants at the service of all citizens [4].

In the context of eGov and NSP, coproduction is an essential requirement for the provision of public good and quality services in a network, presupposing the engagement of citizens, government and organizations. From this perspective, citizens are the main element to define "what" should be produced and "how", and participate in the elaboration, evaluation, and accountability of the process, through the networks of state and non-state actors. Such flexibility to change according to the citizens' interests and needs, by the use of technologies as enabler to connect and engage government and citizens, is described by Marsh [5] as the 'humane smart city'. In the 'commons theory', platforms that support such coproduction can be referred to as digital commons [6]. This can be the case of smart eGov platforms. Such platforms are public digital commons when contribute to transparency, participation, accountability, effectiveness and other open governance principles.

According to Ostrom [7], commons are goods of collective use shared by individuals, and subject to social conflicts, and by: (a) Emphasis on social interaction; (b) Common objectives, rules and standards; (c) Practices of sharing and distribution of power relations; (d) Institutions for decision-making, and; (e) Governance [8,9]. In turn, the concept of commons has advanced, and has become richer and more diversified, as is the case of collective and collaborative production of content mediated by digital and open resources—such as Wikipedia or Linux [10]. This has become a recurring practice in certain organizations, thus contributing to the creation of a collective and adaptive creative intelligence [11]. These collaborative efforts and practices can be characterized as digital commons [6,12].

To complement this understanding, it is useful to refer to Pacheco's [13] view-particularly when considering knowledge as a type of commons involved in information and communication technologies (ICTs). He describes a new type of commons. That is the digital common, and defined as follows: "digital commons is a resource based on information and communication technology, shared by groups and integrated in a value chain, under principles of equity, coproduction and sustainability".

In fact, through eGov platforms or portals, public administration presents its identity, purpose and achievements, provides services and information, providing access and interaction with citizens, as well as understanding their needs, and increasing transparency and the participation of society in government actions [14]. In addition, eGov platforms can be considered tools to promote knowledge sharing, providing users with resources to promote the dissemination of knowledge and interaction between different actors and government [15]. In this sense, the importance of knowledge management is recognized in public administration, since it deals with information and knowledge about citizens, companies, market, laws and policy. Such deliverables and the level of government-to-society relationship can be analyzed according to the maturity level that eGov platforms present.

Maturity models for eGov platforms, in turn, are structured in stages (from basic to advanced). These models provide a way to classify eGov platforms (according to the services, features and functionalities offered), and can be used as a guide to help public administrations improve the quality and efficiency of their eGov portals [16]. In spite of the existence of approaches for the evaluation of different characteristics of eGov platforms $[17,18]$, there is a need for means to evaluate elements that may characterize such platforms as digital commons and, more specifically, to assess their potential of promoting social commons. During the last years, we have developed the Municipal eGov Platform Assessment Model (MEPA) that is a model to assess eGov platforms as digital commons [18]. MEPA allows the identification and evaluation of several factors related to digital commons principals.

In this paper, we present MEPA and its application in the evaluation of 903 official websites of Brazilian cities, and discuss its potential to help public managers to use eGov as integral smart cities instruments. The results of this research underlines the limitations in the municipal eGov platforms in Brazil. Only a few municipalities effectively manage to provide services so that the population can fulfill its role of participation and coproduction. From the sample surveyed, in approximately $7 \%$ of the municipality platforms, it was possible to verify a higher maturity level for the feasibility of the commons offered by the government, since the highest levels of maturity (fifth, fourth and third levels) 
were identified in only 66 Brazilian municipalities. The vast majority of Brazilian eGov platforms still offer simple, easy-to-access information or services, or just online transactions, and remaining at the first and second maturity levels. Therefore, eGov's actions and projects need to be rethought in Brazil, in terms of services, infrastructure, governance and financial resources, to achieve higher levels of eGov maturity.

\section{Research Design and Method}

The MEPA model was developed by empirical research, based on 'design science research' (DSR) method [19], according to the following steps: (1) Identify problem and motivate; (2) Define the objectives of a solution; (3) Design and development; (4) Demonstration; (5) Evaluation; and (6) Communication. In the following sections the development stages of the model according to the DSR.

\subsection{Problem Identification and Motivation}

Ostrom [7] describes that eight principles are fundamental to the sustainable management of commons. These are delimitation, context appropriation, participation, monitoring, proportionate sanctions, affordable conflict resolution, autonomy, and adhocracy. These principles were originally formulated by the author from an examination and analysis of more than 5000 case studies, through which it was possible to verify why some communities or individuals organize themselves successfully to manage the commons, and others do not.

Based on these general principles, there is a need to establish the means to evaluate its presence on eGov platforms of Brazilian municipalities. The platforms offer different services in terms of scope, scope and quality, influenced interaction between stakeholders and government, knowledge sharing and the possibility of coproducing the public good in a sustainable and sustainable manner, according to the level of their maturity.

Therefore, the research problem presented in this paper seeks to answer the following questions: (1) How to relate the maturity of eGov platforms with the instrumentation of commons promotion? and; (2) What is the situation of eGov platforms in Brazilian municipalities, in relation to their potential for promoting commons principles?

The MEPA problem and motivation are, hence, contextualized in multiple domains. Citizen coproduction and public governance are public management subjects. Electronic government platforms and human smart cities are contemporaneous multidisciplinary fields, and commons a general theory suitable as a reference to several complex community-based problems. Our first step was to establish a reference concept table, with the main research construct. The result is presented in Table 1.

Our research problem was to check municipal websites maturity regarding the promotion of commons and citizen participation. In order to do so, we have combined the seven conceptual multidisciplinary constructs presented in Figure 1.

As can be seen in Figure 1, the research problem combines the notions of municipal websites as eGov solutions, that can potentially help public managers to foster citizen participation by means (or towards) digital commons. Besides the specific constructs presented in Table 1 and illustrated in Figure 1, the MEPA design was based on both commons principles [20] and New Public Service (NPS) elements [4], as indicated in Table 2. 
Table 1. Conceptual references of MEPA.

\begin{tabular}{ccc}
\hline Construct & Definition & Authors \\
\hline Humane smart city & $\begin{array}{c}\text { It is a place flexible to change according to its } \\
\text { citizens' wishes, Interests and needs, by the use of } \\
\text { technologies as enabler to connect and engage } \\
\text { government and citizens, aiming to rebuild, } \\
\text { recreate, and motivate urban communities, } \\
\text { stimulating and supporting their collaboration } \\
\text { activities, leading to general increase of } \\
\text { social well-being. }\end{array}$ & Marsh (2013) \\
Citizen participation & $\begin{array}{c}\text { Interaction of citizens and administrators, } \\
\text { concerned with public policy decisions and } \\
\text { public services (Callahan, 2007). }\end{array}$ & Ostrom (1978) \\
Public governance & $\begin{array}{c}\text { Formal and informal arrangements that } \\
\text { determine how public decisions are made and } \\
\text { how public actions are carried out. }\end{array}$ & OECD (2018) \\
\hline New public service & $\begin{array}{c}\text { A paradigm of public management that focuses } \\
\text { on the public interest, the coproduction of the } \\
\text { common good, transparency, accountability and } \\
\text { the participation of society. }\end{array}$ & Denhardt (2012) \\
\hline Knowledge management & $\begin{array}{c}\text { Involving the means by which public } \\
\text { administration mainly promotes the sharing and } \\
\text { dissemination of knowledge through } \\
\text { eGov platforms. }\end{array}$ & Nah et al., 2005 \\
\hline E-Government (eGov) & $\begin{array}{c}\text { It is the use of information technology to produce } \\
\text { and distribute customer-oriented, more } \\
\text { cost-effective, differentiated and better } \\
\text { public services. }\end{array}$ & Holmes (2001) \\
\hline
\end{tabular}

It is an assessment model composed of at least four high-level eGov applications requirements:

eGov maturity assessment

(a) current state of maturity and capability

identification, (b) benchmark with other eGov

Valdés et al. (2011)

applications; (c) innovation roadmap; and (d)

discretion as to whether or not to follow.

\begin{tabular}{ccc}
\hline Commons & $\begin{array}{c}\text { Resource shared by a group of people attempting } \\
\text { to solve social problems. }\end{array}$ & Fisher and Fortmann (2010) \\
\hline Resources available in information and \\
communication technology platforms \\
Digital commons & $\begin{array}{c}\text { (i.e., digital), shared by a group (i.e., commons), } \\
\text { integrated in a value chain (i.e., intangible asset) } \\
\text { and performed by agents, either as a content or as } \\
\text { a process, valuable on a given domain } \\
\text { (i.e., knowledge). }\end{array}$ & Pacheco (2014) \\
\hline
\end{tabular}

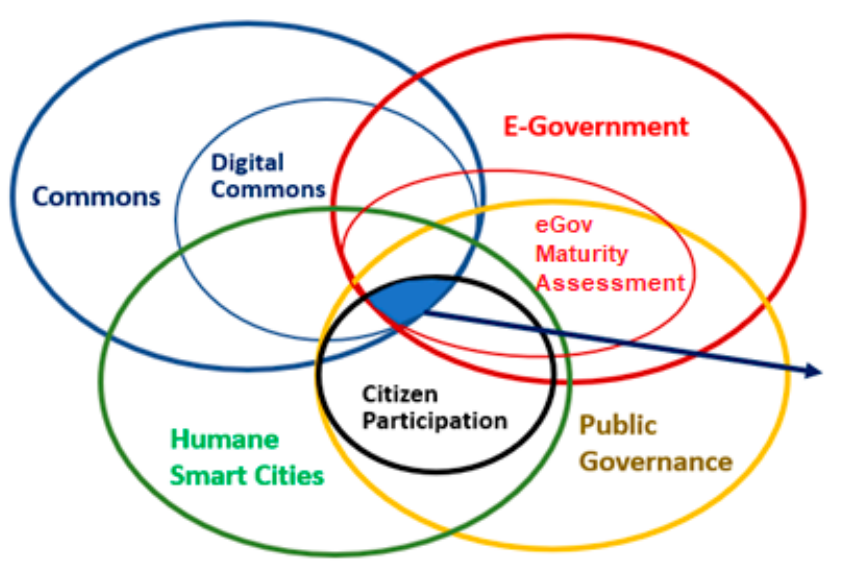

How are

municipal

websites

maturity

regarding

citizen

participation?

Figure 1. Research problem and conceptual constructs. 
Table 2. Commons principles and New Public Service elements (derived from References [4,20]).

\begin{tabular}{|c|c|}
\hline Commons Principles & NSP Elements \\
\hline $\begin{array}{c}\text { Delimitation } \\
\text { Define clear boundaries }\end{array}$ & $\begin{array}{l}\text { Inclusion and access } \\
\text { Access information based on education, } \\
\text { open government, free communication, } \\
\text { and open discussion }\end{array}$ \\
\hline $\begin{array}{l}\text { Adequacy of context } \\
\text { Match rules governing commons use to local needs and } \\
\text { conditions }\end{array}$ & $\begin{array}{l}\text { Civic engagement } \\
\text { Serve citizens, not customers }\end{array}$ \\
\hline $\begin{array}{c}\text { Participation and coproduction } \\
\text { Ensure that the ones affected by the rules can participate } \\
\text { in regulatory changes }\end{array}$ & $\begin{array}{l}\text { Coproduction } \\
\text { Promote collective efforts and collaborative processes }\end{array}$ \\
\hline $\begin{array}{l}\text { Monitoring } \\
\text { Develop a system carried out by community members for } \\
\text { monitoring member's behavior }\end{array}$ & $\begin{array}{l}\text { Transparency and publicity } \\
\text { Greater participation responds to call for greater } \\
\text { transparency and accountability in government }\end{array}$ \\
\hline $\begin{array}{l}\text { Proportionate sanctions and rewards } \\
\text { Use graduated sanctions for rule violators }\end{array}$ & $\begin{array}{l}\text { Accountability } \\
\text { Public servants must attend to law, community values, } \\
\text { political norms, professional standards, } \\
\text { and citizen interests }\end{array}$ \\
\hline $\begin{array}{l}\text { Resolubility } \\
\text { Provide accessible and low-cost means to dispute } \\
\text { resolution }\end{array}$ & $\begin{array}{l}\text { Shared responsibility } \\
\text { Create shared interests and shared responsibility }\end{array}$ \\
\hline $\begin{array}{c}\text { Autonomy } \\
\text { Make sure that rule-making rights are respected by } \\
\text { outside authorities }\end{array}$ & Reaffirmation of values of democracy/citizenship \\
\hline $\begin{array}{l}\text { Adhocracy } \\
\text { Governing the common resource in based on nested tiers } \\
\text { from the lowest level up to the entire interconnected } \\
\text { system }\end{array}$ & $\begin{array}{l}\text { Decentralization of power } \\
\text { Collaborative structures with leadership shared } \\
\text { internally and externally }\end{array}$ \\
\hline
\end{tabular}

Although the relations in Table 2 are not linear (i.e., a commons principle can be related to more than one NPS element, and vice-versa), they help to relate eGov platform services to both public commons and public decision-making. By relating commons principles to NPS elements, the MEPA model opens the possibility of eGov platform assessment in both views, first as digital commons potential promoters and, second as an instrument to support contemporaneous public management. Particularly to NPS, the MEPA analysis is concerned with:

1. Transparency and publicity: The concern of municipalities to comply with current legislation, through the publication and dissemination of information, guidelines, recommendations and open data;

2. Civic engagement: Resources to interested parties, so that they can develop activities in their communities or workplaces through social networks and media, or the services offered, seeking to assert their interests, to provide or receive common goods, or to participate in some level of the political decision-making process;

3. Inclusion and access: Services to help including citizens, public or private bodies in life in society, reducing differences;

4. Shared responsibility: Municipalities efforts to build a collective and shared notion of common, economic and socially viable good;

5. Reaffirmation of values of democracy and citizenship, power decentralization, coproduction and accountability: Services and functionalities for the concrete involvement of all stakeholders, in the definition and active participation of the decision on how the public service will be delivered, and, ultimately, how the common good will be coproduced.

Additionally, MEPA has also a conceptual relationship between the commons theory and eGov maturity assessment, as illustrated in Table 3. 
Table 3. Relationship between eGov maturity levels and commons principles.

\begin{tabular}{ccc}
\hline eGov Maturity Level & Description & Commons Principles \\
\hline First Level & $\begin{array}{c}\text { The portal offers easy access to simple } \\
\text { information and services }\end{array}$ & Delimitation and monitoring \\
\hline Second Level & The portal enables online transactions & Adequacy of context \\
Third Level & $\begin{array}{c}\text { The portal allows access to different } \\
\text { sites and services, with only } \\
\text { one authentication }\end{array}$ & Resolubility \\
\hline Fourth Level & $\begin{array}{c}\text { The portal enables interoperability } \\
\text { between government systems and sites }\end{array}$ & Adhocracy \\
\hline Fifth Level & $\begin{array}{c}\text { The portal allows the personalization of } \\
\text { the services offered to the users }\end{array}$ & $\begin{array}{c}\text { Proportionate sanctions and rewards, } \\
\text { autonomy, } \\
\text { participation and coproduction }\end{array}$ \\
\hline
\end{tabular}

The notion of a citizen as a client was proposed by 'new public management'. In the NPS framework, as proposed by Robert and Jane Denhardt [4], there fourth principle sets "serve citizens not customers".

We have developed MEPA considering coproduction as an essential process to do so. Citizens should participate in the creation, development and evolution of the services promoted by the public administration. In order to do so, the channels of communication and interaction must be effectively provided, so that citizens have an active and independent role. They should be able to comment, request, evaluate, and vote for public services satisfaction as well as on the effectiveness of electronic platform they are using.

In this view, citizens no longer play a secondary role, such as a solicitor at the mercy of the public administration, or as a customer who will "consume" the products and services of a menu, but rather of a co-producer, who participates and collaborates dynamically and actively in the evolution of the products and services that it is receiving from the public administration.

In summary, MEPA design was achieved by the conceptual and practical alignment of principles and procedures from commons, NPS, and eGov maturity analysis. Its ultimate goal is to allow the verification of the eGov platform maturity in relation to the common good, according to different levels of instrumentation and services. MEPA evaluations aim to help public managers to promote commons through eGov solutions.

\subsection{Objectives of Finding a Solution}

Municipal websites are, first, eGov solutions and, as such, subjected to maturity assessment. The proposal solution, however, should go further eGov common maturity analysis. More than check for technological and public services effectiveness, the maturity assessment should also reveal the potential of municipal websites promoting citizen participation. To this end, the instrument should enable the analysis of the commons' principles present in eGov platforms of Brazilian municipalities, also considering elements of NPS and knowledge management, with emphasis on how platforms promote participation and sharing of between the different actors in society.

\subsection{Design and Development}

Different approaches are proposed in the literature for the analysis of eGov platforms in order to characterize their level of maturity $[11,15,17,21-28]$. In common, such approaches cover the breadth of the services assembled by the platform and the level of sophistication of delivery $[16,29,30]$ and the government's relationship with different stakeholders in society [31].

During the research of other models of maturity of e-Government platforms, we found other models that presented some level of similarity with MEPA, as is the case of the methodology presented by Fietkiewicz, Mainka and Stock [32]. Indeed, there is some similarity and points of contact between the two models. However, each model proposes to conduct a different analysis. The methodology presented 
by Fietkiewicz, Mainka and Stock [32], measures the maturity of e-Government, the usability of the navigation systems, and investigate the boundary documents available on the governmental websites.

The MEPA model, in turn, proposes to investigate the maturity of the municipal electronic government platforms in smart cities, considering the digital commons and citizens coproduction. MEPA was elaborated considering the following aspects: (1) Analyze the new service public [4] and knowledge sharing as factors of relationship between eGov maturity and commons principles, according to Ostrom [7]; (2) Establish a comparative framework between dimensions and maturity factors of Electronic Government (eGov), based on Holmes [17] and the principles of commons [7]; (3) Create a maturity assessment tool of Brazilian Municipal e-Government platforms, as commons promoters; (4) Apply the maturity assessment tool to Brazilian municipalities, and; (5) Analyze the results obtained, under the lens of participation and coproduction. The MEPA model does not use, primarily, criteria such as usability navigation systems, or documents that are transacted and made available between municipal sites. The two models apply two different approaches.

In this research, we have established an eGov maturity assessment including factors regarding citizen participation. This was developed based on commons general principles and by the adaptation of eGov maturity questionnaires to include checking for citizen participation related factors. The development of the work was carried out according to the following steps:

1. Systematic review of the literature for the composition of the preliminary evaluation instrument;

2. Evaluation of the preliminary version of the data collection instrument with specialists;

3. Application of the revised instrument in the pre-test stage;

4. Validation of intermediate analysis of the results achieved and of the data collection instrument with the support of specialists in the construction of items and measures;

5. Application of the evaluation instrument.

In the first step, in order to define the items that should compose the evaluation instrument, a systematic review of the literature was carried out, looking for elements in the literature that could characterize the relationship between open government data, coproduction, commons, governance, electronic government, and knowledge management. Therefore, the terms "open government", "commons", "governance", "eGov*" or "electronic government", "knowledge management" and "co*production" were combined to search the main journal bases. The search was performed on the ISI-Web of Knowledge/Web of Science databases; Scopus; Ebsco; Compendex, and ProQuest, and Google Scholar. Of the total of 54 articles found, 35 were selected after reading them and used to support the elaboration of the data collection instrument.

The literature review resulted in the definition of 56 items that formed the initial evaluation instrument. The initial instrument was evaluated by specialists and applied in the evaluation of 264 electronic platforms of Brazilian municipalities in the pre-test phase. The final version of the instrument is composed of 41 items and was configured considering the feedback from the pre-test phase. The 41 items were organized into groups by their affinity (in terms of functionality or characteristics), in order to make the filling of the questionnaire simpler and more intuitive. Table 4 presents nine groups created as well as their definition.

In Table 5 we list the items of the evaluation instrument. Each item was evaluated by means of an application instrument including the response possibilities 1 for "has the characteristic" and 0 for "does not have the characteristic". 
Table 4. Item groups and their description.

\begin{tabular}{|c|c|}
\hline Group & Description \\
\hline $\begin{array}{l}\text { 1. Open data, information and public services are freely } \\
\text { available to users }\end{array}$ & $\begin{array}{c}\text { Citizens have the right to free access to public services and } \\
\text { information, to exercise their participation, to improve } \\
\text { service delivery, to monitor administration, and to } \\
\text { expand democracy [1]. }\end{array}$ \\
\hline $\begin{array}{l}\text { 2. The platform offers open data, institutional and } \\
\text { transparency information, and other topics }\end{array}$ & $\begin{array}{l}\text { The digital environment provides greater transparency, } \\
\text { facilitating access to information for citizens, allowing the } \\
\text { monitoring of government actions, projects and decisions [12]. }\end{array}$ \\
\hline $\begin{array}{l}\text { 3. The platform offers features for interaction with other } \\
\text { users or with those responsible for the platform }\end{array}$ & $\begin{array}{l}\text { Citizens should be aware of the communication channels } \\
\text { available to contact the public administration, and have } \\
\text { access in an easy, accessible and low-cost way [33]. }\end{array}$ \\
\hline $\begin{array}{l}\text { 4. The platform provides resources for users to vote or } \\
\text { make recommendations }\end{array}$ & $\begin{array}{c}\text { Public administration should provide channels of } \\
\text { communication, based on citizen participation, together with } \\
\text { the assumptions of democratic decision-making processes } \\
\text { in society [34]. }\end{array}$ \\
\hline $\begin{array}{l}\text { 5. The platform offers capabilities for downloading data } \\
\text { (in various formats, machine-readable) }\end{array}$ & $\begin{array}{l}\text { Open data must be reachable and can be physically accessed } \\
\text { by download [35]. }\end{array}$ \\
\hline 6. The platform provides open search/search capabilities & $\begin{array}{l}\text { It should be possible to conduct research by various means to } \\
\text { assist users in finding relevant open data [36]. }\end{array}$ \\
\hline 7. The platform is accessible in mobile version & $\begin{array}{l}\text { Citizens have the right to access public services and } \\
\text { information, freely using ICT resources to access electronic } \\
\text { platforms—desktop, mobile or tablet [37]. }\end{array}$ \\
\hline $\begin{array}{l}\text { 8. Quality of data and information offered by } \\
\text { the platform }\end{array}$ & $\begin{array}{l}\text { Well-informed citizens can better combat corruption, nepotism, } \\
\text { and government inaccuracy. On the other hand, } \\
\text { without accurate information, it is difficult to achieve effective } \\
\text { citizen involvement in decision-making processes [38]. }\end{array}$ \\
\hline $\begin{array}{l}\text { 9. The platform provides tools for knowledge } \\
\text { management }\end{array}$ & $\begin{array}{l}\text { The GC is essential for the success of } \\
\text { e-Government initiatives [39]. }\end{array}$ \\
\hline
\end{tabular}

Table 5. Evaluation instrument items.

\begin{tabular}{cc}
\hline \multicolumn{1}{c}{ Item } & Commons Principles \\
\hline $\begin{array}{c}\text { 1. Does the platform require no prior registration of users? } \\
\text { 2. Does the platform identify the services available to } \\
\text { each stakeholder? } \\
\text { services usage? }\end{array}$ & Delimitation \\
\hline $\begin{array}{c}\text { 3. Does the platform provide stakeholders with guidelines for } \\
\text { 4. Does the platform have terms of use for the services, } \\
\text { informing the rights and responsibilities of stakeholders? }\end{array}$ & Delimitation \\
\hline $\begin{array}{c}\text { 5. Does the platform present terms of use for the services, } \\
\text { informing penalties in case of noncompliance? }\end{array}$ & Sanctions and rewards \\
\hline $\begin{array}{c}\text { 6. Does the platform disclose at least an index of use of the } \\
\text { services provided? }\end{array}$ & Sanctions and rewards \\
\hline $\begin{array}{c}\text { 7. Does the platform provide updated news about } \\
\text { the municipality? }\end{array}$ & Monitoring \\
\hline $\begin{array}{c}\text { 8. Does the platform provide additional information } \\
\text { (economic, cultural, tourist, historical, geographic, ethnic, } \\
\text { according to location or region)? }\end{array}$ & Monitoring \\
\hline $\begin{array}{c}\text { 9. Does the platform provide digital media - employing at least } \\
\text { one of the following services? Podcast, interactive maps, } \\
\text { videos, digital documents, web radio? }\end{array}$ & Context and adequacy \\
\hline
\end{tabular}


Table 5. Cont.

\begin{tabular}{|c|c|}
\hline Item & Commons Principles \\
\hline $\begin{array}{l}\text { 10. Does the platform provide relevant legislation to the } \\
\text { municipality? (It may be any type of legislation, as follows: } \\
\text { Laws, Master Plan, Urban Zoning, Code of Works, Taxpayer's } \\
\text { Manual, normative instructions, decree, ordinances, opinions, } \\
\text { resolutions, etc.) }\end{array}$ & Monitoring \\
\hline 11. Does the platform provide access to the Official Gazette? & Monitoring \\
\hline $\begin{array}{l}\text { 12. Does the platform provide access to the municipality's } \\
\text { financial information? (availability of government documents } \\
\text { for collection, movement of the treasury and financial } \\
\text { application of public resources - balance sheets, } \\
\text { financial statements) }\end{array}$ & Monitoring \\
\hline $\begin{array}{l}\text { 13. Does the platform provide content related to } \\
\text { digital inclusion? }\end{array}$ & Delimitation \\
\hline $\begin{array}{l}\text { 14. Does the platform provide access to the municipality's } \\
\text { transparency information? }\end{array}$ & Monitoring \\
\hline $\begin{array}{l}\text { 15. Does the platform provide access to procurement and } \\
\text { bidding by the municipality? }\end{array}$ & Monitoring \\
\hline $\begin{array}{l}\text { 16. Does the platform provide access to at least one municipal } \\
\text { offices website/portal? }\end{array}$ & Adhocracy \\
\hline $\begin{array}{l}\text { 17. Does the platform provide access to at least } \\
1 \text { website/portal of a municipal body? }\end{array}$ & Adhocracy \\
\hline $\begin{array}{l}\text { 18. Does the platform provide access to at least one website or } \\
\text { portal of the municipality's attorney general's office? }\end{array}$ & Adhocracy \\
\hline 19. Does the platform provide open data? & Autonomy \\
\hline $\begin{array}{l}\text { 20. Open data is available in at least one of the following } \\
\text { formats: JSON, XML, CSV, ODS or RDF? }\end{array}$ & Context and adequacy \\
\hline 21. Can the open data available on the portal be downloaded? & Context and adequacy \\
\hline $\begin{array}{l}\text { 22. Does the platform provide information about open data? } \\
\text { (example: usage policies, category, identification, description, } \\
\text { update frequency, etc.) }\end{array}$ & Delimitation \\
\hline 23. Does the platform provide open data search? & Context and adequacy \\
\hline $\begin{array}{l}\text { 24. The platform provides a list of frequently asked questions } \\
\text { (FAQ - Frequently Asked Questions) }\end{array}$ & Resolubility \\
\hline $\begin{array}{l}\text { 25. Does the platform provide at least one communication } \\
\text { channel for complaints, questions, criticisms or compliments? } \\
\text { (example: Ombudsman) }\end{array}$ & Resolubility \\
\hline $\begin{array}{l}\text { 26. Does the platform provide instant online service? (via chat } \\
\text { or similar tool) }\end{array}$ & Resolubility \\
\hline $\begin{array}{l}\text { 27. Does the platform allow integration with social networks? } \\
\text { (made up of groups that share common interests) }\end{array}$ & Resolubility \\
\hline $\begin{array}{l}\text { 28. Does the platform provide collaborative virtual spaces? } \\
\text { (facilitates the meeting and interaction between people who are } \\
\text { not physically together) }\end{array}$ & Participation and coproduction \\
\hline $\begin{array}{l}\text { 29. Does the platform provide blogs or microblogs? } \\
\text { (example twitter) }\end{array}$ & Participation and coproduction \\
\hline $\begin{array}{l}\text { 30. Does the platform allow the formation of communities of } \\
\text { practice? (e.g., to create and share common skills, knowledge, } \\
\text { and experiences) }\end{array}$ & Autonomy \\
\hline $\begin{array}{l}\text { 31. Does the platform allow you to choose the most relevant } \\
\text { services? (which may be due to the functionality of the } \\
\text { platform, or through network resources or social media) }\end{array}$ & Autonomy \\
\hline $\begin{array}{l}\text { 32. Can stakeholders use the network or social media features } \\
\text { offered by the platform? }\end{array}$ & Delimitation \\
\hline 33. Does the platform offer features for electronic voting? & Autonomy \\
\hline
\end{tabular}


Table 5. Cont.

\begin{tabular}{cc}
\hline Item & Commons Principles \\
\hline $\begin{array}{c}\text { 34. Does the platform provide services for the composition of } \\
\text { the decision-making agenda involving } \\
\text { population participation? }\end{array}$ & Autonomy \\
\hline $\begin{array}{c}\text { 36. Does the platform provide features for recommending } \\
\text { open data? }\end{array}$ & Participation and coproduction \\
\hline recommending services? & Participation and coproduction \\
\hline the best open data? & Participation and coproduction \\
\hline $\begin{array}{c}\text { 37. Does the platform provide resources for voting on what are } \\
\text { arest services? }\end{array}$ & Participation and coproduction \\
\hline $\begin{array}{c}\text { 38. Does the platform provide resources for voting on which } \\
\text { 40. Does the platform provide tools for knowledge } \\
\text { management? (such as thesauri, classification schemes, } \\
\text { taxonomies and ontologies, knowledge maps and mailing lists) }\end{array}$ & Context and adequacy \\
\hline $\begin{array}{c}\text { 41. Does the platform provide up-to-date knowledge resources? } \\
\text { (such as lessons learned, good working practices, etc.) }\end{array}$ & Context and adequacy \\
\hline
\end{tabular}

\subsection{Demonstration}

In this phase the DSR method requires the presentation of a proof of concept in order to demonstrate the efficacy of the proposal to solve the problem. The MEPA model was built under simplicity and ease of use guidelines. The items that compose the MEPA questionnaire were developed considering the principles of the Commons [7] and the New Public Service [4].

In order to evaluate the criteria in all digital commons' maturity dimensions, the MEPA model has a questionnaire, with questions about the eGov platform and the municipal website. MEPA's questions were structured in Google Forms, used by the data researchers to register the answers they found out when checking a particular municipal website. Hence, each research data registered their answers manually, after assessing the municipal website, checking whether or not the electronic platform has the characteristic under analysis. This method of collecting data on websites is based on References [40-43].

The application of the MEPA model was performed only on the websites (electronic platforms) of the municipal public administration. Nevertheless, several items of the questionnaire aim to analyze whether the website allows the integration, interaction, voting and publication of references in relation to the services provided, through social media. It also verifies whether the website can be accessed and used on mobile devices.

After completing the data collection, the answers are organized in data sheets. MEPA researchers perform data processing (via descriptive statistics), calculate frequency of occurrence and draw graphs, classified into categories of analysis (by "size", geographical region, and municipality size) and, highlights results (findings), revealing municipality digital commons maturity rankings. For the effective application of the MEPA, the researchers underwent a training, so that everyone had knowledge of how to access the questionnaire online (using Google Forms); later, we defined a set of electronic municipal platforms for the researchers; in turn, each researcher, using the online questionnaire, accessed the municipal platforms of his responsibility, filling in the answers, and reporting findings that he considered relevant. This way, we were able to evaluate 903 electronic Brazilian municipal platforms, following the same standards and criteria of analysis, in a short period of time, with a high degree of reliability.

\subsection{Evaluation}

In this DSR phase we analyzed how well the proposed model provides solutions to the research problem by comparing the eGov maturity assessment pursued with MEPA results. The strategy was 
based on the comparison between expert's opinion, literature findings and MEPA results. MEPA metrics and techniques of analysis, and the way the evaluation was conducted led to results similar to cities websites situations described in the literature, as well as by the empirical observation of the researchers.

An example is the ninth publication of the eGov development benchmarking from United Nations Department of Economic and Social Affairs (UNDESA) [44]. In this survey, Brazil is in the 51st position of better eGov services. The country stands out in the basic indicators, such as the existence of a web page of the main public agencies, data supply and indicators on government websites. However, the country has unsatisfactory levels of online eGov services.

According to MEPA survey, municipal Brazilian eGov services offer little citizen participation in public policy decision making over the Internet, but is well positioned to provide information in consultations (note 93 out of 100). A large part of the municipalities visited have available electronic platform, data supply and indicators in governmental sites, in some level. However, unsatisfactory levels were identified in the offer of online services, and in the actions of digital inclusion. Comparing the results of the "online participation" carried out by the UN research with MEPA results, the eGov platforms of the Brazilian municipalities offer few services for citizen participation in the decisions, but they provide diverse information and news.

\subsection{Communication}

In this phase of DSR method, the researchers should communicate the problem, its relevance, and how their proposal presents a novelty or inedita achievements. The MEPA model was fully described in a PhD dissertation [18]. MEPA was discussed not only in the academic forum, its application has been considered beyond the municipal sphere, including the state and federal spheres in Brazil. Recently, the model was the basis of discussion with the Court of Accounts of the State of Santa Catarina, when it served as the basis for the discussion of the electronic government model for the municipalities of that state.

\section{Application of the Model to Brazilian Municipalities}

As described before, the MEPA model was developed based on different theoretical foundations and knowledge fields. In this section, we present the application of the MEPA model to Brazilian municipalities.

\subsection{Brazilian Municipalities and Large-Scale Model Application}

According to the Brazilian official national institute of geography and statistics (IBGE), the country has 5,570 cities. We have applied the MEPA model in 903 municipal websites (i.e., $16.2 \%$ of total municipalities), in cities from all five Brazilian regions, as indicated in Table 6.

Table 6. Population and sample-large-scale application.

\begin{tabular}{cc}
\hline Brazilian Region & Quantity of Municipalities \\
\hline South & 300 \\
Southeast & 300 \\
Midwest & 91 \\
Northeast & 111 \\
North & 101 \\
\hline Total & 903 \\
\hline
\end{tabular}

\subsection{MEPA Positive Responses in the Evaluated Brazilian Municipalities}

The total 903 municipal websites that were analyzed are from large (291), medium (453), and small cities (159). These websites were checked in all eight digital common maturity dimensions. In Table 6 the percentages of positive answers are presented, according to each digital commons' maturity. 
As it can be seen in Table 7, around $82 \%$ of the municipal websites have positive Monitoring and $72 \%$ are adequate to its context. These positive results are followed by a good Delimitation in about $61 \%$, and good Resolubility in almost $60 \%$ of the evaluated municipal websites.

Table 7. Dimensions and frequency of positive responses.

\begin{tabular}{cc}
\hline Region & Frequency (\%) \\
\hline Monitoring & $82.77 \%$ \\
Context adequacy & $72.04 \%$ \\
Delimitation & $61.26 \%$ \\
Resolubility & $59.86 \%$ \\
Autonomy & $25.20 \%$ \\
Adhocracy & $22.22 \%$ \\
Participation and coproduction & $21.96 \%$ \\
Sanctioning and rewards & $10.96 \%$ \\
\hline
\end{tabular}

The investigation revealed that the evaluated municipal eGov platforms offer the following information services: (a) Updated news, information on history, economy, tourism, and other relevant facts, using digital media; (b) Monitoring of public agents, through services aimed at the dissemination and publicity of information on Transparency and Open Data of the municipality in question, including municipal budget, laws and projects, purchases, bids and contracts, official gazette; and (c) Communication channels with the ombudsman of the municipality.

Some results in Table 7 reveal a low commitment to commons principals. The evaluated municipal websites offer low level of services related to Autonomy (25.20\%), Adhocracy (22.22\%), Participation and Coproduction (21.96\%), and Sanctioning and Rewards (10.96\%).

Therefore, fewer than one fourth of the evaluated municipal platforms provide services related to civic engagement, platform inclusion and assessment, shared accountability, regulation participation, and decentralized power. This is coherent with low levels of Autonomy (i.e., the website is limited to eGov national or regional legislation) and Adhocracy (i.e., rules and commitment is limited to eGov public owners). Additionally, a low level of sanctioning and rewarding about how parties use the platforms reveals the lack of incentives to good use or punishment when users break rules.

From the results obtained, it was possible to perceive that the electronic platforms of large municipalities presented a higher frequency of positive responses, mainly those located in the South and Southeast regions of Brazil, with higher GDP and Human Development Index (HDI) indices.

In the MEPA model, e-Gov platforms can be verified as potential instruments to promote commons and support public management. This is done by classifying MEPA answers according to Commons and NSP principles. In Table 8 we present the results of the 903 evaluated Brazilian municipalities.

According to the results in Table 8, the vast majority of Brazilian municipal eGov have Transparency and Publicity services (82.77\%). This is related to Monitoring services, often related with authorities concerns about constitutional principles and laws that obligate govern to open and disseminate public data, information, guidelines, and recommendations. Around $72 \%$ of all Brazilian municipal eGov analyzed have services that help to promote Civic Engagement. In fact, most of platforms use web, social media or other services to allow users identify and/or develop activities in their communities or places of work. In time, by attending citizen interests, an eGov platform will accumulate data and information useful to support political decision-making or even to provide/or receive common goods. 
Table 8. Brazilian municipal eGov regarding commons and NSP principles.

\begin{tabular}{ccc}
\hline Commons Principles & NSP Elements & Frequency (\%) \\
\hline Monitoring & Transparency and publicity & $82.77 \%$ \\
Adequacy of context & Civic engagement & $72.04 \%$ \\
Delimitation & Inclusion and access & $61.26 \%$ \\
Resolubility & Shared responsibility & $59.86 \%$ \\
Autonomy & Democracy/citizenship values & $25.20 \%$ \\
Adhocracy & Decentralization of power & $22.22 \%$ \\
Participation and coproduction & Coproduction & $21.96 \%$ \\
Proportionate sanctions and rewards & Accountability & $25.20 \%$ \\
\hline
\end{tabular}

Another important finding was the fact that $61.26 \%$ of the municipal eGov websites have services related to inclusion and access to all citizens. Besides being recommended by law, digital inclusion can reduce differences between social classes, educational levels, ages, gender, disability, social prejudice or racial. Six out of 10 (59.86\%) of the Brazilian municipal eGov platforms analyzed have services related to share responsibility and conflict resolution. These services help municipalities to build a collective and shared notion of common, economically and socially viable good. This includes citizens, companies, elected representatives and administrators in a broader system of governance, aimed at promoting citizenship and serving the public interest.

The lowest rates of commons and NPS principles are in services that help to promote democracy and citizenship values $(25.20 \%)$, power decentralization $(22.22 \%)$, coproduction $(21.96 \%)$ and accountability (10.96\%). Brazilian municipal governments provide an insufficient number of services and functionalities for the concrete involvement of all stakeholders. Municipal platforms can do more to engage citizens in defining and participate in decision making on how the public service will be delivered. This requires focus on deliberative democracy based on citizen participation, and shared responsibilities at levels of government and public governance.

\subsection{Brazilian Municipalities' Common Ranking}

One of MEPA model goals is to allow public managers to compare different eGov municipalities regarding their potential to promote commons. This is done by comparing commons principle eGov rates, calculated by weighted scales, where the highest levels mean more citizen participation and coproduction, as shown in Table 9.

Table 9. MEPA commons dimension weights and maturity levels.

\begin{tabular}{ccccc}
\hline Maturity Level & Commons Principles & Weight & Qty Items & Range \\
\hline First Level & Delimitation & 1 & 14 & 1 to 41 \\
Second Level & Monitoring & 2 & 6 & 42 to 59 \\
Third Level & Adequacy of context & 3 & 4 & 60 to 70 \\
Fourth Level & Resolubility & 4 & 3 & 71 to 769 \\
Fifth Level & Adhocracy & 5 & 14 & 80 to 120 \\
& Proportionate sanctions and rewards & Autonomy & & \\
\hline
\end{tabular}

Each municipal eGov reaches a specific score calculated as follows: by summing the responses to the 41 items (positive response $=1$ and negative response $=0$ ), multiplied by the weight of the respective principle item (according to Table 9). In addition, knowing the weights assigned to each commons' principle, and the number of items per Level, it is possible to establish ranges for each Level (as shown in Table 8).

In Table 10, we present the rank results, according to each MEPA maturity level. 
Table 10. Number of municipalities by level of maturity.

\begin{tabular}{ccc}
\hline Maturity Level & Quantity of Municipalities & Percentage (\%) \\
\hline First Level & 4 & $0.44 \%$ \\
Second Level & 14 & $1.55 \%$ \\
Third Level & 48 & $5.32 \%$ \\
Fourth Level & 398 & $44.08 \%$ \\
Fifth Level & 439 & $48.62 \%$ \\
\hline Total & 903 & \\
\hline
\end{tabular}

Almost half of the Brazilian cities have ( 439 or $48.62 \%$ of the evaluated platforms) are still in the First Level of maturity, offering simple information or services, easy to access. Another significant number of cities (398 platforms or $44.08 \%$ ) are in the Second Level of maturity, including users the possibility of performing online transactions. Only 48 of the evaluated municipal platforms $(5.32 \%)$ are in the Third Level of maturity, adding access to different sites and services, with a single authentication. There are 14 platforms (1.55\%) at the Fourth Level, enabling interoperability between systems and sites other than government. Additionally, only four platforms ( $0.44 \%)$ are in the Fifth Level of maturity, including the personalization of the services offered to users.

In summary, among the 903-municipal eGov platforms analyzed in Brazil, 837 (92.7\%) are at the basic levels of maturity. Only a few cities provide effective services to promote citizen participation and coproduction. Brazilian municipal eGov platforms do not yet include the population, and do not provide enough means for the interested parties to participate in the elaboration and coproduction of laws, projects, budgets, as well as the services themselves and features offered by the platform, being at the mercy of the services offered by the exclusive initiative of public agencies.

In many of the platforms visited, no evidence was found to demonstrate compliance with basic requirements, such as the availability of up-to-date information and online services. For example, in terms of transparency and open data, many municipalities simply provide information that is required by legislation, often incomplete, unstructured or difficult to understand, and that does not strictly and effectively promote the transparency and publicity of actions undertaken in the public sector. The absence of services and information, or the difficulty in finding and understanding them, distances citizens from the public administration, and prevent manifestations, requests, criticisms, suggestions or compliments. The lack of inclusion of stakeholders and low understanding of the functioning, organization and execution of the actions of public services undermine citizen participation and public co-production.

\subsection{International Benchmarking}

MEPA benchmark is conducted by comparing eGov municipalities results with municipal eGov that fully comply with the commons principles proposed in its data collection instrument. We have found two eGov platforms that meet all MEPA criteria with maximum excellence grade: London/UK (see https://www.london.gov.uk/) and Singapore (see https://www.gov.sg/). By comparing the evaluated Brazilian platforms with these two international references, it is possible to recommend the following eGov good practices to improve MEPA grades:

1. Interface: Apply well-structured and elaborated interface, facilitating the access to the services of interest of the user;

2. Tutorial: Offer guidelines and easy identification of available services, based on user profiles of the interested party (citizen, company, server, tourist, etc.);

3. Content: Caveats about the services, informing rights, responsibilities and penalties to the interested parties;

4. Content: Offer municipality up-to-date news/information (economic, cultural, tourist, historical, geographic, ethnic); 
5. Social eGov: Digital media (e.g., Podcast, interactive maps, videos, digital documents, web radio);

6. Openness: Provide services for government transparency;

7. Openness: Apply open government practices, providing open data, with the possibility of download and readable by machine;

8. Interoperability: Provide access to other government agencies;

9. Communication: Channels to interact with stakeholders (e.g., Ombudsman), with registration, follow-up and closing of the request;

10. Readiness: Provide instant online services;

11. Social eGov: Allow the integration and use of the social networks;

12. Interface: Allow the choice or recommendation of more relevant services;

13. Mobile eGov: Be accessible in mobile version;

14. Knowledge management: Include resources for management and knowledge sharing.

\section{Concluding Remarks}

Smart cities (particularly the humane smart cities) call for new governance models where public authorities and citizens build sustainable relationships [45]. Both commons and NPS principles relate sustainable public relations with collective governance based on citizen participation and coproduction. Additionally, smart cities also call for efficient use of information technologies, this is also a requirement for mature eGov platforms. In this study, we presented the MEPA model to accurately assess eGov platforms' performance in terms of citizen participation and coproduction to offer high quality public services. In other words, by using numerous criteria, MEPA verifies eGov platforms regarding the commons, NPS, and maturity of electronic government dimensions.

In the smart cities practice, by assessing eGov platforms as common promoters, MEPA can be a highly useful tool to evaluate the levels of citizens empowerment, collective co-creation, and public authorities' commitment to use digital technologies to develop social sense of belonging and identity. The large-scale application of MEPA in 903 Brazilian municipalities reveals the general outcome of city eGov platforms as digital commons promoters being immature/underdeveloped. There are only a few eGov municipal platforms that are in higher grades of maturity; and these are from cities with higher budgets and from more developed regions of Brazil. An international benchmark indicated several points to help public authorities to foster eGov platforms towards a higher level of commons maturity.

The MEPA model and its large-scale application indicate that in order to develop digital commons promoters, eGov platforms' authorities have to: (a) Enable citizens, public and private agencies, and government at large taking into account of their respective roles and responsibilities; (b) Develop effective mechanisms for conflict resolution (i.e., fast, affordable, and proportionate sanctioning); (c) Develop sustainable and perennial initiatives, appropriate to the context to which they refer; (d) Adopt coproduction and citizen participation as guiding principles; (e) Understand that the assets of society, more than public, are collective goods and responsibilities, and; (f) Define clear and effective rules to monitor and govern the interaction of diffuse and collective interests, considering that different communities can share the same common good.

As part of our prospective work, the MEPA model research will be expanded to its application to other levels of government (including the legislative and judicial branches). Moreover, we will adopt/develop a longitudinal data collection and analysis method to the evaluated Brazilian cities. Furthermore, we will adapt and apply the model in other countries (particularly to compare developed and developing country practices), and include eGov cross-referencing indicators such as quantity and frequency of stakeholders' eGov access. Lastly, particularly focusing on smart cities, we will relate the MEPA model with smart/knowledge-based city models (such as smart and knowledge-based urban development $[27,45-48])$. This will not only add another dimension to digital commons maturity analysis, but also will contribute to relate eGov platform maturity with smart cities requirements, e.g., smart governance. 
Author Contributions: Conceptualization, M.J.R.R., D.S. and R.C.S.P.; Investigation, M.J.R.R.; Writing - Original Draft Preparation, M.J.R.R., D.S. and R.C.S.P.; Writing - Review \& Editing, T.Y.

Funding: This study was financed in part by the Coordenação de Aperfeiçoamento de Pessoal de Nível Superior Brasil (CAPES) - Finance Code 001.

Acknowledgments: The authors thank anonymous referees for their constructive comments on an earlier version of the manuscript.

Conflicts of Interest: The authors declare no conflict of interest.

\section{References}

1. Bart'h, J.; Fietkiewicz, K.J.; Gremm, J.; Hartmann, S.; Ilhan, A.; Mainka, A.; Meschede, C.; Stock, W.G. Informational urbanism, A Conceptual Framework of Smart Cities. In Proceedings of the 50th Hawaii International Conference on System Sciences, Waikoloa Village, HI, USA, 4-7 January 2017; IEEE Computer Society: Washington, DC, USA, 2017; pp. 2814-2823.

2. Caragliu, A.; Del Bo, C.; Nijkamp, P. Smart Cities in Europe. J. Urban Technol. 2011, 18, 65-82. [CrossRef]

3. Anttiroiko, A.V.; Valkama, P.; Bailey, S.J. Smart cities in the new service economy: building platforms for smart services. Ai Soc. 2014, 29, 323-334. [CrossRef]

4. Denhardt, J.V.; Denhardt, R.B. The New Public Service: Serving, Not Steering; ME.Sharpe: London, UK; New York, NY, USA, 2003; Available online: https://epdf.pub/the-new-public-service-serving-not-steering. html (accessed on 12 July 2019).

5. Marsh, J. (Ed.) The Human Smart Cities Cookbook. 2013. Available online: www.peripheria.eu (accessed on 12 July 2019).

6. Hess, C.; Ostrom, E. A Framework for Analyzing the Knowledge Commons: A chapter from Understanding Knowledge as a Commons: From Theory to Practice. 2005. Available online: https://surface.syr.edu/sul/21 (accessed on 12 July 2019).

7. Ostrom, E. Governing the Commons: The Evolution of Institutions for Collective Action; Cambridge University Press: Cambridge, UK, 1990.

8. Hardt, M.; Negri, A. Commonwealth; Harvard University Press: Cambridge, MA, USA, 2009.

9. Chourabi, H.; Nam, T.; Walker, S.; Gil-Garcia, J.R.; Mellouli, S.; Nahon, K.; Scholl, H.J. Understanding Smart Cities: An Integrative Framework. In Proceedings of the 45th Hawaii International Conference on System Sciences, Maui, HI, USA, 4-7 January 2012; pp. 2289-2297. [CrossRef]

10. Nam, T.; Pardo, T. Conceptualizing smart city with dimensions of technology, people, and institutions. In Proceedings of the 12th Annual International Digital Government Research Conference: Digital Government Innovation in Challenging Times, College Park, MD, USA, 12-15 June 2011; ACM: New York, NY, USA, 2001; pp. 282-291. [CrossRef]

11. West, D.M. E-Government and the Transformation of Service Delivery and Citizen Attitudes. Public Adm. Rev. 2004, 64, 15-27. [CrossRef]

12. Bollier, D. The Growth of the Commons Paradigm. Understanding Knowledge as a Commons. 2007, p. 27. Available online: http://dlc.dlib.indiana.edu/dlc/bitstream/handle/10535/4975/GrowthofCommonsParadigm. pdf?sequence $=1 \&$ is Allowed $=y$ (accessed on 12 July 2019).

13. Pacheco, C.S.R. Coprodução em Ciência, Tecnologia e Inovação: Fundamentos e visões. In Interdisciplinaridade: Universidade e Inovação Social e Tecnológica, 1st ed.; CRV Editora: Curitiba, Brazil, 2016; pp. 21-62. Available online: https://www.researchgate.net/publication/307977522_ Coproducao_em_Ciencia_Tecnologia_e_Inovacao_fundamentos_e_visoes?amp\%3BenrichSource= Y292ZXJQYWdlOzMwNzk3NzUyMjtBUzo0MDUxNDExNzQ5MzE0NjdAMTQ3MzYwNDU5MTg4Ng\% 3D\%3D\&amp\%3Bel=1_x_3\&amp\%3B_esc=publicationCoverPdf (accessed on 12 July 2019).

14. Pinho, J.A.G.D. Investigando portais de governo eletrônico de estados no Brasil: Muita tecnologia, pouca democracia. RAP Revista de Administração Pública-Rio de Janeiro 2008, 42, 471-493. Available online: http://www.scielo.br/pdf/rap/v42n3/a03v42n3 (accessed on 12 July 2019). [CrossRef]

15. Hassan, B.; Alireza, I.; Majideh, S. E- government portals: A knowledge management study. Electron. Libr. 2012, 30, 89-102. Available online: http://www.emeraldinsight.com/doi/pdfplus/10.1108/02640471211204088 (accessed on 12 July 2019). 
16. Fath-Allah, A.; Cheikhi, L.; Al-Qutaish, R.E.; Idri, A. E-Government maturity models: A comparative study. Int. J. Softw. Eng. Appl. 2014, 5, 71. [CrossRef]

17. Holmes, D. eGov: eBusiness Strategies for Government; Nicholas Brealey Publishing: Boston, MA, USA, 2001.

18. Rotta, M.J.R. As Plataformas de Governo Eletrônico e seu Potencial para a Promoção dos Princípios dos Commons: O caso dos Municípios Brasileiros. Doutorado em Engenharia e Gestão do Conhecimento; Universidade Federal de Santa Catarina, UFSC: Trindade, Brazil, 2018; Available online: http://btd.egc.ufsc.br/wp-content/uploads/ 2018/12/Maur\%C3\%ADcio-Rotta.pdf (accessed on 12 July 2019).

19. Hevner, A.; Chateerjee, S. Design Research in Information Systems Theory and Practice Forewords; Springer: New York, NY, USA, 2012. [CrossRef]

20. Ostrom, E. Citizen Participation and Policing: What Do We Know? J. Volunt. Action Res. 1978, 7, $102-108$. [CrossRef]

21. Layne, K.; Lee, J. Developing fully functional E-Government: A four stage model. Gov. Inf. Q. 2001, 18, 122-136. [CrossRef]

22. Andersen, K.V.; Henriksen, H.Z. E-Government maturity models: Extension of the Layne and Lee model. Gov. Inf. Q. 2006, 23, 236-248. [CrossRef]

23. United Nation (UN). UN E-Government Survey 2012: E-Government for the People. Available online: http://unpan1.un.org/intradoc/groups/public/documents/un/unpan048065.pdf (accessed on 12 July 2019).

24. Alonso-Muñoz, L. Transparency and Political Monitoring in the Digital Environment: Towards a Typology of Citizen-Driven Platforms. 2007. Available online: https://www.ull.es/publicaciones/latina/072paper/1223/ 73en.html (accessed on 12 July 2019).

25. Almazan, R.S.; Gil-Garcia, J.R. E-Government Portals in Mexico; University at Albany: New York, NY, USA, 2008. [CrossRef]

26. Baum, C.; Maio, A.D. Gartner's Four Phases of e-Government Model; Gartner Group Inc.: Stamford, CO, USA, 2000.

27. Moon, J. The Evolution of E-Government among Municipalities: Rhetoric or Reality? Public Adm. Rev. 2002, 62, 424-433. [CrossRef]

28. Toasaki, Y. e-Government from A User's Perspective; APEC Telecommunication and Information Working Group: Taipei, Taiwan, 2003.

29. Valdés, G.; Solar, M.; Astudillo, H.; Iribarren, M.; Concha, G.; Visconti, M. Conception, development and implementation of an e-Government maturity model in public agencies. Gov. Inf. Q. 2011, 28, 176-187. [CrossRef]

30. Cresswell, A.M.; Pardo, T.A.; Hassan, S. Assessing capability for justice information sharing. In Proceedings of the 8th Annual International Conference on Digital Government Research, Los Angeles, CA, USA, 20-23 May 2007; pp. 122-130. [CrossRef]

31. Alves, A.A.; Moreira, J.M. Cidadania Digital e Democratização Electrónica; SPI: Porto, Portugal, 2004; Available online: http://www.spi.pt/documents/books/inovacao_autarquia/docs/Manual_IV.pdf (accessed on 12 July 2019).

32. Fietkiewicz, K.J.; Mainka, M.; Stock, W.G. eGovernment in cities of the knowledge society. An empirical investigation of Smart Cities' governmental websites. Gov. Inf. Quar. 2017, 34, 75-83. [CrossRef]

33. Bollier, D. The commons, short and sweet. Bollier. Org. 2011. Available online: http://eco-literacy.net/wpcontent/uploads/sites/4/2017/05/introduction-to-the-commons.pdf (accessed on 12 July 2019).

34. Gomes, W. A Democracia Digital e o Problema da Participação Civil Na Decisão Política. Fronteiras-Estudos Midiáticos 2005, 7, 214-222. Available online: http://www.revistas.unisinos.br/index.php/fronteiras/article/ view/6394 (accessed on 12 July 2019).

35. Welle Donker, F.; Van Loenen, B. How to assess the success of the open data ecosystem? Int. J. Digital Earth 2017, 10, 284-306. Available online: http://www.tandfonline.com/doi/abs/10.1080/17538947.2016.1224938 (accessed on 12 July 2019). [CrossRef]

36. Máchová, R.; Lnénicka, M. Evaluating the Quality of Open Data Portals on the National Level. J. Theor. Appl. Electron. Commer. Res. 2017, 12, 21-41. Available online: http://www.scielo.cl/scielo.php?pid=S0718$18762017000100003 \&$ script=sci_arttext (accessed on 12 July 2019).

37. Brazil Ministério do Planejamento. Orçamento e Gestão. Resolução CGPAR 05, de 29 de Setembro de 2015. Available online: http://www.planejamento.gov.br/assuntos/empresas-estatais/legislacao/resolucoes/ rescgpar_05.pdf (accessed on 12 July 2019). 
38. Abdullah, N.N.; Rahman, M.F.A. Access to Government Information in Public Policy Making Process: A Case Study of Kurdistan. Int. Inf. Inst. 2015, 18, 3447. [CrossRef]

39. Gupta, R.; Singh, J. Knowledge Management and Innovation in (e) Government. Int. J. Inf. Comput. Technol. 2014, 4, 1637-1645. Available online: http://www.ripublication.com/irph/ijict_spl/ijictv4n16spl_04.pdf (accessed on 12 July 2019).

40. Pinterits, A.; Treiblmaier, H.; Pollach, I. Environmental websites: An empirical investigation of functionality and accessibility. Int. J. Technol. Policy Manag. 2006, 6, 2006. [CrossRef]

41. Al-Khalifa, H.S. The accessibility of Saudi Arabia government Web sites: An exploratory study. Univ. Access. Inf. Soc. 2010, 10. [CrossRef]

42. Stepchenkova, S.; Tang, L.; Jang, S.S.; Kirilenko, A.P.; Morrison, A.M. Benchmarking CVB website performance: Spatial and structural patterns. Tour. Manag. 2010, 31, 611-620. [CrossRef]

43. Tezza, R.; Bornia, A.C.; Andrade, D.F. Measuring web usability using item response theory: Principles, features and opportunities. Interact. Comput. 2011, 23, 167-175. [CrossRef]

44. United Nation (UN). United Nations E-Government Survey 2016: E-Government in Support of Sustainable Development; United Nations: New York, NY, USA, 2016; Available online: http://workspace.unpan.org/sites/ Internet/Documents/UNPAN96407.pdf (accessed on 12 July 2019).

45. Yigitcanlar, T.; Metaxiotis, K.; Carrillo, F.J. Building Prosperous Knowledge Cities: Policies, Plans and Metrics; Edward Elgar Publishing: Cheltenham, UK, 2012.

46. Yigitcanlar, T.; Kamruzzaman, M.; Buys, L.; Ioppolo, G.; Sabatini-Marques, J.; da Costa, E.M.; Yun, J.J. Understanding 'smart cities': Intertwining development drivers with desired outcomes in a multidimensional framework. Cities 2018, 81, 145-160. [CrossRef]

47. Yigitcanlar, T. Position paper: Benchmarking the performance of global and emerging knowledge cities. Expert Syst. Appl. 2014, 41, 5549-5559. [CrossRef]

48. Trindade, E.P.; Hinnig, M.P.F.; Moreira da Costa, E.; Marques, J.; Bastos, R.; Yigitcanlar, T. Sustainable development of smart cities: A systematic review of the literature. J. Open Innov. Technol. Mark. Complex. 2017, 3, 11. [CrossRef]

(C) 2019 by the authors. Licensee MDPI, Basel, Switzerland. This article is an open access article distributed under the terms and conditions of the Creative Commons Attribution (CC BY) license (http://creativecommons.org/licenses/by/4.0/). 